\title{
Citizens Facing COVID-19: Inequalities and Vulnerabilities of the Working Class The World Before COVID-19
}

\author{
Carl E. D. Pierre \\ Department of science, Faculty of science, University of Liège, Belgium \\ Граждани, изправени пред COVID-19: Неравенства и уязвимости на \\ работническата класа. Светьт преди COVID-19 \\ Карл Пиер \\ Департамент по наука, Факултет по наука, Лиежки университет, Белгия
}

\begin{abstract}
Author Note
Carl E. D. Pierre https://orcid.org/0000-0001-8029-0818
\end{abstract}

The author has no known conflict of interest to disclosure.

Correspondence concerning this article should be addressed to Carl Pierre, University of Liege, Belgium, Place du 20 Août 7, B-4000 Liège. E-mail: cedpierre@uliege.be

\section{Бележки за автора}

Карл Е. Д. Пиер

https://orcid.org/0000-0001-8029-0818

Авторът декларира че няма конфликт на интереси.

Кореспонденцията относно статията трябва да се адресира до: Карл Е. Д. Пиер. Лиеж, Белгийски университет, Place du 20 Août 7, B-4000 Liège. E-mail cedpierre@uliege.be 


\begin{abstract}
This paper relies on recent studies to describe the hardship of working-class people during the COVID-19 crisis, their vulnerabilities, and how social inequalities play a significant role in their exposure to the virus and its more severe and potentially deadly expressions. We show how existing inequalities before the pandemic, along with public policy, create the sanitary, financial, and economic disaster we are facing now. It is crucial to understand the pandemic's impacts on blue-collar workers and state-sponsored measures to fight against it. This essay also shows the need for further research on working-class issues such as their resilience to financial and sanitary hardship.
\end{abstract}

Keywords: inequality, COVID-19, vulnerability, working-class, financial resilience

\title{
Резюме
}

Статията се основава на скорошни проучвания за описване на трудностите на хората, принадлежащи към работническата класа по време на кризата с COVID-19 - на тяхната уязвимост и как социалните неравенства играят основна роля в тяхната изложеност на вируса и неговите по-тежки и потенциално смъртоносни проявления. Показваме как съществуващите неравенства преди пандемията, заедно с публичната политика създават санитарно, финансово и икономическо бедствие, пред което сме изправени сега. Изключително важно е да се разбере въздействието на самата пандемия върху работниците със сини якички, заедно с мерките, финансирани от държавата, и предприети за борба срещу нея. Тази статия показва също така необходимостта от допълнителни изследвания по въпроси на работническата класа, от рода на нейната устойчивост на финансови и хигиенни трудности.

Ключови думи: неравенство, COVID-19, уязвимост, работническа класа, финансова устойчивост 
Citizens Facing COVID-19: Inequalities and Vulnerabilities of the Working

Class.

\section{The World Before COVID-19}

Thanks to globalization, human beings are more and more dependents on collective networks to live and thrive. This ranges from road to digital networks, including public service infrastructure for water, electricity, hospitals, schools, etc. It is not without reason that any restrictions on access to these networks have aroused much resistance among citizens. We can cite as an example throughout the year 2019 the Yellow Vests in France or the citizen revolts in Sudan, Haiti, Chile, Ecuador, or Jordan after increases in gas prices or surtaxes on mobility in general. In hindsight, these premonitory events made it possible to bring to the fore the feeling of downgrading of the middle classes and the pauperization of Europe's working classes (Blundell et al., 2020). Austerity cures in public sectors and cuts in social spending to limit budget deficits are strongly recommended or even imposed by European Union treaties.

These budgetary guidelines have weakened the collective networks on which the most vulnerable citizens rely, especially in crises: public hospitals, unemployment insurance, pensions, various social assistance, etc. The arrival of the COVID-19 pandemic in this context has made it difficult for industries to keep up with the demand for masks, respirators, medical drugs, and other health necessities in many Western countries. The arrival of the COVID-19 pandemic in this context has made it difficult for industries to keep up with the demand for masks, respirators, medical drugs, and other health necessities in many Western countries. Globalization has, therefore, transformed Europe's industrial strongholds into financial ones. The production capacities clearly made the difference between the Chinese and the European management of the epidemic.

When it comes to fighting the pandemic, people do not have the same financial means. People with limited income who cannot perform telework, i.e., the vast majority of the working class, do not have the same standards to fight the pandemic as others. They rely on collective networks for protection.

Studies have shown that low-income people are more likely to develop more severe forms of covid-19 (Bentley, 2020; Doumas et al., 2020).

The pre-pandemic world was already embedded with social inequalities (Bentley, 2020; Blundell et al., 2020). 
We must ask ourselves, why do working-class people are more vulnerable to the COVID-19? And what lessons can we learn from this pandemic moving forward? We must understand both the financial and the sanitary burden this crisis places on blue collars' shoulders and why most countries failed to keep this crisis under control.

The pandemic affects both the health and the finances of working-class people (Bhala et al., 2020; Khunti et al., 2020; Laurencin \& McClinton, 2020; Webb \& Pérez-Stable, 2020).

The northern health systems, with rare exceptions, were very quickly overwhelmed by numerous cases exceeding their respective reception capacities. In order to reduce contaminations, states have started to advocate either for more or less strict confinement measures along with individual mask mandates. In this paper, we will focus on inequality facing COVID-19 as a virus and then inequality in the face of confinement and other sanitary measures taken to stop the disease from spreading.

Our analysis will be based on recent studies, which may not have enough hindsight to be conclusive on the effectiveness of the health and economic level measures to combat the Covid-19 pandemic and the long-lasting effect of the pandemic on the working class.

\section{Differential exposure to COVID-19.}

The likelihood of exposure to the virus increases with movement. The main way people are infected with SARS-CoV-2 is through exposure to respiratory droplets carrying an infectious virus, according to the Center for Disease Control (CDC, 2020; Klompas et al., 2020). It confirms that frequenting crowded places is a significant risk factor. Working-class people tend to use public transportation and usually cannot perform teleworking jobs. They were called essential workers because their labor was needed to keep society functioning. Their jobs often led to physical proximity to others. These low-income jobs in service sectors are crucial to health, transportation, cleaning, restauration, etc. To make matters worse, the financial impossibility to support the cost of their protective equipment, which should be changed regularly, might increase their risk of exposure to the virus.

On the other hand, working families' homes may constitute another major contamination source. These essential workers often live together in limited spaces (Bentley, 2020) due to the high rent cost, especially in big cities like Paris or Brussels. Furthermore, the household is often multigenerational for the same reasons, which may increase the risk of infection with SARS-CoV-2. The World Health Organization has long warned of strong associations between clutter and respiratory tract infections like the SARS-CoV-2 virus 
(CDC, 2020). In spite of the fact that working-class people are more likely to be exposed to the virus, the effects on their bodies may also be more harmful for several reasons.

\section{Differential vulnerability to COVID-19}

In general, serious forms of Covid-19 are relatively rare, but several co-morbid factors can foster their appearance, such as the patient's age, history of cardiovascular or pulmonary disease, diabetes, obesity, etc. The risk of serious illness and death by COVID-19 can be increased for people with poor general health and bad nutrition habits.

The prevalence of these conditions is inversely associated with socioeconomic status (Burström \& Tao, 2020).

The working class, especially the working poor and the unemployed, do not necessarily have the means to look after themselves and feed themselves properly since they are always on a budget. On the other hand, their essential work may have exposed their health to harmful substances in the past or physically exhausted them. They are, therefore, disproportionately affected by chronic diseases and more vulnerable to serious complications with COVID-19.

\section{Differential consequences of COVID-19}

The social and economic consequences of the COVID-19 pandemic will affect the working classes much more severely (Doumas et al., 2020). At the pandemic's peak, around 3 billion human beings had to be confined across the world. The health measures to slow the spread of the virus had the same effect on the economy as the destruction of jobs, drastic reduction of activities, and significant income losses.

The working class is severely affected by the health measures, even despite the State's funding, due to globalization and its inability to perform teleworking jobs (Blundell et al., 2020).

According to many studies, unemployment and confinement affect mental health, favor increased alcohol and psychotropic substances, and enhance the suicide rate and familybased violence.

\section{Pandemic lessons for the working class}

In summary, the COVID-19 pandemic has exacerbated existing inequalities and brought to the fore other inequalities in terms of working-class financial possibilities, such as their ability to cope with the loss of revenue (Burström \& Tao, 2020). The post-COVID-19 world will suffer from one of the worst financial and economic crises in modern history. This 
sanitary situation was worsened by globalization in industrial capacities and cuts on social resilience systems by major countries, especially in the EU. Therefore, it will take time to assess the full-fledged effects of the pandemic. One thing is for sure, and the pandemic has shown how exposed low-income people are to various health hazards and how non-resilient they are in the face of financial hardship. Working-class people are prone to chronic diseases due to the financial arbitrations that their low-income forces upon them every day.

The time will come to evaluate state failures in the months leading up to the sanitary disaster in western democracies. However, an excellent place to start addressing the problems would be to take care of the working class's low financial resilience. This major issue requires much more research and will be determinant for the post-COVID-19 world.

\section{References}

Bentley, G. R. (2020). Don't blame the BAME: Ethnic and structural inequalities in susceptibilities to COVID-19. American Journal of Human Biology, 32(5), e23478. https://doi.org/10.1002/ajhb.23478

Bhala, N., Curry, G., Martineau, A. R., Agyeman, C., \& Bhopal, R. (2020). Sharpening the global focus on ethnicity and race in the time of COVID-19. The Lancet, 395(10328), 1673-1676. https://doi.org/10.1016/S0140-6736(20)31102-8

Blundell, R., Dias, M. C., Joyce, R., \& Xu, X. (2020). COVID 19 and Inequalities*. Fiscal Studies, 41(2), 291-319. https://doi.org/10.1111/1475-5890.12232

Burström, B., \& Tao, W. (2020). Social determinants of health and inequalities in COVID-19. European Journal of Public Health, 30(4), 617-618.

https://doi.org/10.1093/eurpub/ckaa095

CDC. (2020). Health equity considerations and racial and ethnic minority groups. Retrieved September 17, 2020, from https://www.cdc.gov/coronavirus/2019-ncov/needextraprecautions/racial-ethnic-minorities.html

Doumas, M., Patoulias, D., Katsimardou, A., Stavropoulos, K., Imprialos, K., \& Karagiannis, A. (2020). COVID-19 and increased mortality in African Americans: Socioeconomic differences or does the renin angiotensin system also contribute? Journal of Human Hypertension, 34(11), 764-767. https://doi.org/10.1038/s41371-020-0380-y

Khunti, K., Singh, A. K., Pareek, M., \& Hanif, W. (2020). Is ethnicity linked to incidence or outcomes of COVID-19? The BMJ, 369 m1548. https://doi.org/10.1136/bmj.m1548 
Klompas, M., Baker, M. A., \& Rhee, C. (2020). Airborne transmission of SARS-CoV-2: Theoretical considerations and available evidence. JAMA, 324(5), 441. https://doi.org/10.1001/jama.2020.12458

Laurencin, C. T., \& McClinton, A. J. (2020). The COVID-19 pandemic: A call to action to identify and address racial and ethnic disparities. Racial and Ethnic Health Disparities, 7(3), 398-402. https://www.ncbi.nlm.nih.gov/pmc/articles/PMC7166096/

Marmot, M., \& Allen, J. (2020). COVID-19: Exposing and amplifying inequalities. $J$ Epidemiol Community Health, 74(9): 681-682. doi: 10.1007/s40615-020-00756-0 https://doi.org/10.1136/jech-2020-214720

Webb Hooper, M., Nápoles, A. M., \& Pérez-Stable, E. J. (2020). COVID-19 and racial/ethnic disparities. JAMA, 323(24), 2466-2467. https://doi.org/10.1001/jama.2020.8598 